\title{
THE ANALYSIS OF PRICE AND MARKET INTEGRATION OF BANANA COMMODITIES IN LAMPUNG, INDONESIA
}

\author{
Zuhriawati Nur Fatin*, Ekowati Titik, Setiawan Bambang Mulyatno \\ Faculty of Animal and Agriculture Science, University of Diponegoro, Semarang, Indonesia \\ *E-mail: ra.fatin24@gmail.com
}

\begin{abstract}
Price Stability is a price condition since all parts which relate to marketing relationship reach the same information of price with CV $9 \%$ as the threshold value. Market integration is the rate of price movement in a different territory, where the same product will have the same price. Even though it is sold in a different place, the price signal and market information are evenly transmitted. The purpose of this research is to analyze the price stability of banana and to vertically analyze the market integration of banana commodities in Lampung. This research had been done in December 2019. The location election was done purposely. It was located in Lampung with the consideration that Lampung is a region of Indonesia's number one productivity crop of Banana. The used method of this research is a secondarydata analysis method. The data types and sources that are used in this research are secondary data such as the price list in producer and consumer's level of banana in Lampung. The collected secondary data had been time-series data for 10 years recently from 2009 to 2018 or as much as 120 monthly data. The data analysis used analysis variant and testing data by using Johansen's cointegration and VAR. Based from the research showing that the rate of stability for the banana supply in Lampung is stable. The vertical market integration analysis shows that the market at the farmer level is not a long-term relationship related to the consumer level, yet it still has a short-time relationship.
\end{abstract}

\section{KEY WORDS}

Price, market integration, banana, stability.

Banana is one of the fruit kinds which can grow well in Indonesia. Banana is a prime fruit and has the highest production (Fauziah et al., 2015). Hanum et al., (2012) claim that the commodity of banana in Indonesia takes first place among other kinds of fruit both from the cultivation and production sides. Year by year, banana production is more and more increased. According to the department of statistics (2019), in 2017, banana production in Indonesia was 7.162.678 tons and reaching 7.264.379 tons in the next year. The growth value of banana production between 2017 and 2018 which increased every year was 1,42\%.

A commodity of banana is one of the potential commodities which is being managed by the government to support local income rate which might be able to help the local development process. According to BPS's data (2019), the harvest land size of banana commodities in Indonesia in 2018 was 81.289 ha which was spread in 34 provinces in Indonesia. The number of banana commodities in Indonesia in 2018 was 7.264.379 tons with 89,36 tons/ha total productivities. From the total number of production, Lampung gave a great contribution to the number of banana production in Indonesia. According to the ministry of agriculture outlook (2019), Lampung is a province with the highest productive level of banana producers in Indonesia. Shown in 2018, the productive level of banana commodities in Lampung was 141,15 tons/ha with 1.438 .559 tons of production of through 10.192 ha of harvest land size.

The price rate of banana in Lampung is fluctuating within five years. The price of banana at the consumer level from 2014 to 2018 was approximately from Rp 5,000 to Rp 6,700 per $\mathrm{kg}$. According to the data from the ministry of agriculture (2018), the price of banana at the consumer level between 2014 and 2018 fluctuated where it was Rp 5,002.42 per $\mathrm{kg}$ as the lowest price in 2014 and Rp 6,699.33 per $\mathrm{kg}$ as the highest price in 2016, 
whereas Banana commodity price in Lampung at the consumer level in 2018 was Rp $5.870,42$ per $\mathrm{kg}$. It has already experienced a 0,14\% decrease in 2016.

Economic factors which cause interregional price variations are the market force existence, market distortions, and price policies. Price fluctuations with great variations are affairs while price fluctuations with low variations are relatively restrained. Both governments and communities are concerned about the relative food commodity price. The stability of food prices needs to be done for a good and conducive economic development to get political stability and security (Kustriani, 2017). Price stability is one of the targets in Indonesia economic development. This can be seen from the inflation attainment in areas (Naenggolan, 2008).

A price in cities/provinces is stable if the variety of coefficient prices intervenes in $<9 \%$, according to the target of the ministry of trade republic of Indonesia to 2019 (ministry of trade republic of Indonesia, 2015). The availability of accurate and continuous market information is absolutely needed to prevent asymmetric information between producers and consumers. If consumers and producers have accurate and continuous market information, price changing can be quickly responded by market participants so that the decisions can be quickly and correctly accomplished (FAO et al., 2011).

Market integration is the integration of some marketing institutions that are functionally and economically united in a single marketing system. There are two integration approaches of this marketing behavior analysis such as vertical and horizontal integration. Horizontal integration aims to look at the situation between the market and the same commodity while vertical integration aims to look at the situation between the market and the consumer (Asmara and Ardhiani, 2010). The vertical market integration analysis is able to explain the bargaining power between farmers and marketing institutions (Humairoh, 2008). This shows that the commodity's price changing will affect the market integration of commodity. Therefore, the purpose of this research is to analyze the price of banana stability and to analyze the vertical market integration on the commodity of Banana in Lampung.

\section{MATERIALS AND METHODS OF RESEARCH}

The research was accomplished in December 2019. The location election was done intentionally (Purposive). The location was accomplished in Lampung by a consideration that Lampung was Indonesia's number one productivity crop of Banana. The used method in this research is the secondary-data analysis method. According to Andrews et al. (2012), the secondary-data analysis method was research that utilizes the available qualitative and quantitative data to either discover a new problem or test the result of previous research. Qualitative data analysis (theoretical grounded) and quantitative data analysis (statistical analysis) can be used in the research of the secondary-data analysis methods.

The data types and sources used in this research are secondary data added by indepth interview to specifically expand the information. Those, the data types and sources, are secondary data which are the price data at the banana producer and consumer level in Lampung. Secondary data is used as early information in determining research location and as information in answering research purposes. The collected secondary-data is the timeseries data over the last 10 years from 2009-2018.

The used data analyses are using:

1. Analyzing the stability of supply and market integration in Lampung was done by using a coefficient of variation. A coefficient of variation (CV) is a ratio between standard deviation and average, in a percentage, regarding the data spread of the average (Walpole and Mayes, 2000). It is mathematically formulated:

$$
\mathrm{C}_{\mathrm{v}}=\frac{\sigma}{\bar{x}} \times 100 \%
$$

Notes: $\mathrm{C}_{\mathrm{v}}$ - Coefficient of Variation; $\sigma$ - Standard deviation; $\bar{x}$ - Average.

2. To identify the market integration can be done by three steps of analysis such as (1) stationarity test/unit root, (2) causality test, and (3) cointegration test. 
3. Stationarity test. Unit root test is done to know the stationarity of time series data used in the model and the stationarity order of time series data. The time-series data is stationary if the average and variation are constant all the time (Widarjono, 2013). The stationarity data is a necessary condition for analysis of the data time release because it can reduce the error model. The stationarity test on this research uses the augmented dickey-fuller root test (ADF). The formulation of the ADF test on this research as follows:

$$
\Delta P_{t}=a_{0}+\gamma P_{t-1}+\beta_{i} \sum_{j=1}^{m} \Delta P_{t-1}+\varepsilon_{t}
$$

Where: $P_{t}$ - Banana's price variable in the 't' period; $P_{t-1}$ - Banana's price variable in the 'previous' period; $\Delta P_{t}-\mathrm{P}_{\mathrm{t}}-\mathrm{P}_{\mathrm{t}-1} ; \Delta P_{t-1}: \mathrm{P}_{\mathrm{t}-1}-\mathrm{P}_{(\mathrm{t}-1)-1}$; m: number of lag; $a_{0}$ - Intercept; $\beta, \gamma$ - Coefficient of parameter; $\varepsilon_{t}$ - error term.

Hypothesis examinations:

- $\mathrm{H}_{0}: \gamma=0 \rightarrow$ Non-stationary time series data;

- $\mathrm{H}_{\mathrm{I}:} \gamma<0 \rightarrow$ Stationary time-series data.

Examination rules:

- If ADFstatistic > ADFcritical, reject H0, it means there is no unit root in the time series data or it had been stationary;

- If ADFstatistic $\leq$ ADFcritical, reject $\mathrm{HO}$, it means there is a unit root in the time series data or it had not been stationary.

4. Determining the optimal lag. Optimal length of lag is needed to see the effects of every variable to the other variables in the VAR model. The value of the variable lag can affect other variables as it took time for variables to respond to the movements of other variables. The length determination of optimal lag can allow some criteria, namely: Akaike Information Criteria (AIC), Schwartz Information Criteria (SIC), Hannan Quinn Criteria (HQ), Likelihood Ratio (LR), and Final Prediction Error (FPE). Length deremining of optimal lag of this research used Akaike Information Criteria (AIC) derived from the testing results.

5. Cointegration test. The cointegration test used in this research is Johansen's cointegration test by looking at the connection between the price of banana in consumer and producer, and market-level in Lampung. Johansen's cointegration model analogy can be generally formulated as:

$$
\begin{aligned}
& \Delta Y_{t}=A+\sum_{i=1}^{p-1} \pi_{1} \Delta Y_{t-1}+e_{t} \\
& {\left[\begin{array}{l}
X_{t} \\
Y_{t}
\end{array}\right]=Y_{t} ;\left[\begin{array}{l}
a_{1} \\
a_{2}
\end{array}\right]=A ;\left[\begin{array}{ll}
\pi_{11} & \pi_{12} \\
\pi_{21} & \pi_{22}
\end{array}\right]=\pi_{i} ;\left[\begin{array}{l}
X_{t-1} \\
Y_{t-1}
\end{array}\right]=Y_{t-1} ;\left[\begin{array}{l}
\epsilon_{1 t} \\
\epsilon_{2 t}
\end{array}\right]=E_{t}}
\end{aligned}
$$

Where: $X$ - Producer's price $(\mathrm{Rp} / \mathrm{kg})$; $Y$ - Consumer's price $(\mathrm{Rp} / \mathrm{kg}) ; A$ - Coefficient; $\mathrm{E}_{\mathrm{t}}$ - Error component; $\pi_{i}$ - The multiplication result of singular cointegration vector and synchronization velocity parameter.

The cointegration test is done if the observed price variables are not integrated at the level of $/ \mathrm{I}(0)$. It is done to find out whether the integration happens in the long or short term. It uses Johansen's cointegration test at which it could be used to look at the cointegration rank among the variables (Rosadi, 2012). The cointegration test using Johansen's theory has been done by comparing the value of trace statistic (TS) and maximal eigenvalue (ME) to the $t$-statistic critical value. If the value of trace statistic and maximal eigenvalue exceeds the $t$ statistic critical value $(5 \%)$, it may have been that both variables are integrated with others (Kuastri, 2017).

6. Granger's causality test. Causality test is done to look at whether both variables have reciprocal relationship or not, in other words, whether a variable has causality with others because of every variable in research has a chance of being endogenous or 
exogenous variable. The equation of Granger's causality test can be generally formulated as follows:

$$
\begin{aligned}
\Delta X_{\mathrm{t}} & =\sum_{\mathrm{j}=1}^{\mathrm{m}} \theta_{1 j} \Delta \mathrm{X}_{\mathrm{t}-\mathrm{j}}+\sum_{\mathrm{i}=1}^{\mathrm{p}} \beta_{\mathrm{ij}} \Delta \mathrm{Y}_{\mathrm{t}-\mathrm{j}}+\varepsilon_{1 \mathrm{t}} \\
\Delta Y_{\mathrm{t}} & =\sum_{\mathrm{j}=1}^{\mathrm{m}} \theta_{2 j} \Delta \mathrm{X}_{\mathrm{t}-\mathrm{j}}+\sum_{\mathrm{i}=1}^{\mathrm{p}} \beta_{\mathrm{ij}} \Delta \mathrm{Y}_{\mathrm{t}-\mathrm{j}}+\varepsilon_{2 \mathrm{t}}
\end{aligned}
$$

Where: X - Producer's price (Rp/kg); Y - Consumer's price $(\mathrm{Rp} / \mathrm{kg}) ; \beta_{i j}$ - Singular cointegration vector; $\theta_{1 j}$ - Synchronization velocity parameter; $\mathrm{E}_{\mathrm{t}}$ - Error component.

Hypothesis:

- $\mathrm{H}_{0}: \mu=0 \rightarrow$ There is no causal relationship between a variable with the others;

- $\mathrm{H}_{\mathrm{I}:} \mu \neq 0 \rightarrow$ there is causal relationship between a variable with the others. Examination rules:

- $\mathrm{HO}$ is accepted if the probability value is $>0,05$ which means there is no causal relationship between a variable and the others;

- $\mathrm{H}_{\mathrm{l}}$ is accepted if the probability value is $\leq 0,05$ which means there is a causal relationship between a variable and the others.

7. The test of Vector Error Correction Model (VECM). Vector Error Correction Model test is used when the variable is not stationary at level but stationary at the same differentiation and cointegrated levels. VECM measures how the price deviation can return to the state of balance (Hendy and Juselius, 2000). VECM is a model of VAR (vector autoregression) which has been restricted (Enders, 2004). This model is used for non-stationary data but has an integrated potential. This additional restriction must be administered because of the existence of data form which are not stationary at level but integrated (Paramita et al., 2015). The used VAR/VECM model in this research is as follows:

$$
\begin{aligned}
& P P_{t}=\alpha_{0}+\sum_{i=1}^{p} \alpha_{i} P P_{t-1}+\sum_{i=1}^{p} \beta_{i} P G_{t-1}+\varepsilon_{1 t} \\
& P G_{t}=\delta_{0}+\sum_{i=1}^{p} \delta_{i} P P_{t-1}+\sum_{i=1}^{p} \sigma_{i} P G_{t-1}+\varepsilon_{1 t}
\end{aligned}
$$

Where: PPt = Banana's price at producer level in the "t" period; PPt-1 = Lag of Banana's price at producer level in the "t" period; $P G t=$ Banana's price at the consumer level in the " $t$ " period; PGt-1 = Lag of Banana's price at the consumer level in the "t" period; $E=$ vector with $\mathrm{n} \times 1$ size; $\mathrm{p}=$ Length of the lag.

VECM/VAR analysis describes the relationship of short-term dynamic balance and long-term balance in a system of equation. While there is a long-term balance among the markets, there is a deviation of the short-term balance relationship. So, it can be said that the cointegration equation as the representation of a long-term balance relationship among the markets and short-term balance relationship will probably vary significantly. So, VECM/VAR is a combination of short-term and long-term relationships among the price variables of different markets (Irawan and Rosmayanti, 2007).

\section{RESULTS AND DISCUSSION}

Based on the average calculations of the coefficient value of variation from the monthly banana price at the farmer and consumer levels, the achieved result is that the average of coefficient value of variation in the price of banana at the farmer level is $0.66 \%$ and the price 
of bananas at the consumer level is $0.99 \%$ (table 1 ). The total value is less than $9 \%$, which means the price of bananas at the farmer and consumer level is stable. This is suitable for the ministry of trade of RI decision (2015) which measured the threshold of a price would be stable if the coefficient value of the variation did not exceed $9 \%$. A stable price from both farmers and consumers shows that the price information is well transmitted. Moreover, it shows that the distribution of banana in Lampung has been evenly spread so that there is no imbalance number of banana supplies in every territory which can cause unstable prices. According to Irawan (2007), the commodity price of agriculture was unstable because of the uneven distribution for every commodity so it could cause high effect of price change caused by the rareness of goods that can affect the elevation of commodity price in the certain territory.

Table 1 - The coefficient of variation of banana price at farmer and consumer level

\begin{tabular}{|c|c|c|}
\hline Year & Farmer's CV & Consumer's CV \\
\hline & \multicolumn{2}{|c|}{ 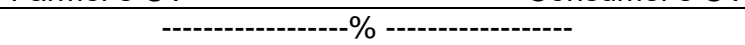 } \\
\hline 2009 & 0,89 & 0,60 \\
\hline 2010 & 1,12 & 0,94 \\
\hline 2011 & 0,72 & 0,61 \\
\hline 2012 & 0,67 & 0,92 \\
\hline 2013 & 0,67 & 2,11 \\
\hline 2014 & 0,67 & 1,36 \\
\hline 2015 & 0,58 & 1,13 \\
\hline 2016 & 0,38 & 0,38 \\
\hline 2017 & 0,41 & 0,87 \\
\hline 2018 & 0,54 & 1,02 \\
\hline Average & 0,66 & 0,99 \\
\hline
\end{tabular}

Source: Managed research data, 2019.

Based on the stationarity test of the data of banana price from the referenced market in Lampung, the achieved result is as in table 2.

Table 2 - The result of ADF test at level

\begin{tabular}{cccc}
\hline \hline Variable & Critical Value 5\% & t-stat & Prob \\
\hline Farmer & -2.885863 & -0.774222 & 0.8224 \\
Consumer & -2.885863 & -1.786368 & 0.3857 \\
\hline
\end{tabular}

Source: Managed research data, 2019.

The data stationarity test on time series data is used to avoid a high value of error because time series data, generally, has a high standard deviation, so time-series test needs to be done to have a low probability of error. The data stationarity test that has been used is using augmented dicky fuller's test (ADF). Based on the ADF test to the data stationarity test, there is a variable of the banana price at both farmer and consumer level in Lampung which is not stationary at level. This is caused by ADF statistic value < ADF critical value $5 \%$ $(0,774222<2,885863$ and $1,786368<2,885863)$ and its probability is more than 0,05 $(0,8224>0,05$ and $0,3857>0,05)$.

Table 3 - The result of ADF test at First Difference Level

\begin{tabular}{cccc}
\hline \hline Variable & Critical Value 5\% & t-stat & Prob \\
\hline Farmer & -2.885863 & -12.44779 & 0.0000 \\
Consumer & -2.885863 & -10.67498 & 0.0000 \\
\hline
\end{tabular}

Source: Managed research data, 2019.

Based on data stationarity test using ADF test (Table 3), the achieved result is that the variable of banana price at both farmer and consumer level in Lampung which is not stationary at first difference level. This is caused by ADF statistic value > ADF critical value 
$5 \%(12,44779>2,885863$ and $10,67498>2,885863)$ and its probability is less than 0,05 $(0,0000<0,05)$.

Optimal lag test analysis shows results as shown in table 4.

Table 4 - Optimal Lag Test

\begin{tabular}{ccccccc}
\hline \hline Lag & LogL & LR & FPE & AIC & SC & HQ \\
\hline 0 & -1816.627 & NA & $4.35 \mathrm{e}+11$ & 32.47547 & 32.52402 & 32.49517 \\
1 & -1448.835 & 715.8792 & $6.57 \mathrm{e}+08$ & 25.97920 & $26.12484^{*}$ & 26.03829 \\
2 & -1440.706 & $15.53289^{\star}$ & $6.11 \mathrm{e}+08^{*}$ & $25.90547^{\star}$ & 26.14819 & $26.00395^{\star}$ \\
3 & -1437.132 & 6.700910 & $6.15 \mathrm{e}+08$ & 25.91308 & 26.25289 & 26.05095 \\
4 & -1434.618 & 4.624744 & $6.32 \mathrm{e}+08$ & 25.93960 & 26.37651 & 26.11687 \\
5 & -1433.771 & 1.527214 & $6.69 \mathrm{e}+08$ & 25.99591 & 26.52990 & 26.21257 \\
\hline
\end{tabular}

Source: Managed research data, 2019.

Based on the optimal lag test, known that an optimal lag with the AIC criteria (Akaike Information Criteria) indicates that lag 2 is optimal (Table 4.) The use of lag 2 as an optimal lag in a model which is shown from the economic side has implications that all variables in the model are interrelated with each other not only at the present period but also at the two previous periods. The value of lag 2 shows that there has been an effect of Banana price change in Lampung from the farmers and consumers for two periods. Nuraeni et al. (2015) said that the length of optimal lag is needed to see the effect of every variable on the other variables in the VAR model. The lag value of a variable can affect the other variables to respond to the movement of other variables.

Based on Johansen's cointegration tests, resulting in such results in table 5.

Table 5 - The result of Johansen's cointegration test

\begin{tabular}{|c|c|c|c|c|c|c|}
\hline $\begin{array}{c}\text { Number of } \\
\text { cointegration }\end{array}$ & $\begin{array}{l}\text { Trace } \\
\text { Stat } \\
\end{array}$ & $\begin{array}{c}\text { Critical Value } \\
5 \% \\
\end{array}$ & Prob. & $\begin{array}{l}\text { Max-Eigen } \\
\text { Stat }\end{array}$ & $\begin{array}{c}\text { Critical Value } \\
5 \% \\
\end{array}$ & Prob. \\
\hline \multicolumn{7}{|c|}{ Relationship between Farmers and consumers } \\
\hline None & 12.54687 & 15.49471 & 0.1325 & 9.889737 & 14.26460 & 0.2193 \\
\hline At most 1 & 2.657136 & 3.841466 & 0.1031 & 2.657136 & 3.841466 & 0.1031 \\
\hline
\end{tabular}

Source: Managed research data, 2019.

The result of Johansen cointegration tests based on either a statistic trace or a maxeigen stat against the banana prices at both farmer and consumer levels shows no cointegration. This is shown from a trace statistics value which is less than the critical value at $5 \%(12,54687)$ and a max-stat which is smaller than the critical value at $5 \%(9.889737)$ and its larger probability value than 0.05 (0.2193). According to this, there would be no integration in the long time between the price of bananas at the farmer and consumer level. None of price integration means that, in a long time, the price of banana at farmer and retailer level will not be integrated. This is going to cost for both farmers and consumers, as the market takes full control of changing the sale price of Banana in the market. This has happened because farmers generally sell bananas directly to market merchants and customers obtain them in the market, thus they who are getting benefits because of this condition are the market traders. On the other hand, although it does not take a long-term interest, there is a possibility of the price of bananas at the farmer level related to the price of bananas at the consumer level in the short-term that can be covered through VECM/VAR analysis.

Based on Granger's causality tests, resulting in such results in table 6.

Table 6 - Granger's causality tast result Granger

\begin{tabular}{|c|c|c|c|}
\hline Null Hypothesis: & Obs. & F-Statistic & Prob. \\
\hline X2 does not Granger Cause X1 & 118 & 11.1750 & 4.E-05 \\
\hline $\mathrm{X} 1$ does not Granger Cause $\mathrm{X} 2$ & & 0.38748 & 0.6797 \\
\hline
\end{tabular}

Notes: X1 - Farmers; X2 - Consumers. 
According to Granger's causality test, the result shows that a one-way causality relationship relatively happens between farmer and consumer level (prob. $<05$ or 0.00004 ) where price changes at the farmer level will affect consumer price. This will not happen oppositely even if customers obtain bananas at a high price, the margin of marketing is only enjoyed by the marketers at the market level. Granger's causality test is conducted to know a causal relationship or causality between two variables. The results of Granger's causality test can reflect a relationship between two variables that have two possibilities: one-direction or two-direction relationships. Katrakilidis (2008) stated that causality test is conducted to look at interrelationship or causality relationship between two price variables and to identify the dominant market in seeding prices on other markets. According to Jumiana et al. (2018), the granger's causality test step is carried out to understand the relationship of variables within a certain lag during the lag testing.

The VARD model is used in time series data which is not stationary on a level but stationary on a first difference level and not cointegrated. None of the long-term relationships or balances between two markets does not mean that they unlikely connect in a short period of time. The decision-taking step towards VAR (vector autoregression) is explained by Kuntoro (2015) by comparing the value of the ' $t$ ' table and ' $t$ ' calculus. The value of the ' $t$ ' table which is greater than that of ' $t$ ' calculus shows that there are significant variables.

The result of VARD Analysis (vector autorea difference) indicates that conversion of the banana price at farmer levels has been only affected by a change in consumer prices in the previous month to 0.350615 and is not affected by its own price. Meanwhile, the banana price of consumers will never change because of the price change at both the farmer level and its own level. This is significantly proved by the VARD test (vector autorea difference) which has been done that shows the variable of banana prices at both farmer and consumer level is not significant to affect the price change at consumer level.

The coefficient value of banana price changing at the farmer level reflects that every price changes at the consumer level in the short term will affect the price of bananas at the farmer level. The positive value indicates that every thousand units of the banana price increase which is received by customers will give a price change of banana at farmer level as Rp 350,62. Even though these are not great, they have been able to reflect that the increase of banana prices received by consumers is equally felt by the farmers, which means that the price transmission has been channeled to the farmer level.

\section{CONCLUSION}

Based on the performed research, conclusions drawn as follows:

- The rate of stability for the banana supply in Lampung is stable;

- The vertical market integration analysis shows that the market at the farmer level is not a long-term relationship related to the consumer level, yet it still has a short-time relationship.

\section{REFERENCES}

1. Andrews, L., A. Higgins., M.W. Andrews and J.G. Lalor. 2012. Classic grounded theory to analyse secondary data reality and reflections. J. The Grounded Theory Review 11 (1): $12-26$.

2. Asmara, R. and R. Ardhiani. 2010. Integrasi pasar dalam system pemasaran bawang merah. J. AGRISE X (3): $164-176$.

3. Central Agency on Statistics. 2019. Produksi Pisang Menurut Provinsi, Tahun 2014 2018. https://www.pertanian.go.id/home/index.php?show=repo\&fileNum=296 Accessed: Semarang, August $1^{\text {st }} 2019$.

4. FAO, IFAD, IMF. 2011. Price Volatility in Food and Agricultural Markets: Policy Responses. Interagency Report to The G20 on Food Price Volatility. 
5. Fauziah, E., E. Widowati and E. Atmaka. 2015. Kajian karakteristik sensoris and fisikokimia fruit leather pisang tanduk (Musa corniculata) dengan penambahan berbagai konsentrasi karagenan. J. Aplikasi Teknologi Pangan 4 (1): 11 - 16.

6. Hanum, F., I.M.D. Kaban and M.A. Tarigan. 2012. Reaksi pectin dari kulit buah pisang raja (Musa sapientum). J. Teknik Kimia USU 1 (2): 21 - 26.

7. Hendy, D.F. and K. Juselius. 2000. Explaining cointegration analysis: part 1. The Energy Journal. International Association for Energy. Economy. 21 (1): 1 - 42.

8. Irawan, A. and D. Rosmayanti. 2007. Analisis integrasi pasar beras di Bengkulu. J. Agro Ekonomi 25 (1): $37-54$.

9. Irawan, B. 2007. Fluktuasi harga, transmisi harga and marjin pemasaran sayuran and buah. J. Analisis Kebijakan Pertanian 5 (4): 358 - 373.

10. Jumiana, W., Azhar and E. Marsudi. 2018. Analisis variasi harga and integrasi pasar vertikal cabai merah di Kabupaten Gayo Lues. J. Ilmiah Mahasiswa Pertanian Unsyiah 3 (4): $577-593$.

11. Katrakilidis, C. 2008. Testing for market integration and the law of one price: an application to selected European milk markets. J. Econ Res. 5 (1): 93 - 104.

12. The Ministry of Trade of RI. 2015. Rencana Strategis Kementerian Perdagangan Periode 2015-2019. Kementerian Perdagangan RI, Jakarta.

13. The Ministry of Agriculture of RI. 2018. Statistik Pertanian. Pusat Data and Sistem Informasi Petanian, Kementerian Pertanian RI, Jakarta.

14. Kustiari, R. 2017. Analisis harga and integrasi pasar bawang merah di Indonesia. J. Agroekonomi 35 (2): $77-87$.

15. Nainggolan, K. 2008. Analisis stabilitas pasokan, permintaan and harga komoditas pangan. J. Analisis Kebijakan Pertanian 6 (2): 114 - 139.

16. Nuraeni, D., R. Anindita and Syafrijal. 2015. Analisis variasi harga and integrasi pasar bawang merah di Jawa Barat. J. Habitat 26 (3): 163 - 172.

17. Outlook Kementan. 2019. Five years recent data. Https://www.pertanian.go.id/home/?show=page\&act=view\&id=61. Accessed: September $10^{\text {th }}, 2019$, Semarang.

18. Walpole, R.E. and R.H. Mayes. 2000. Probabilitas and Statistika ed. 6. Prenhallindo, Jakarta.

19. Widarjono, A. 2013. Ekonometrika: Pengantar and Aplikasinya. Ekonosia, Jakarta. 